\title{
Role of Nature in Creation of Iranian Myths
}

\author{
Abolghasem Dadvar ${ }^{1} \&$ Roya Rouzbahani ${ }^{1}$ \\ ${ }^{1}$ Faculty of Arts, Alzahra University, Iran \\ Correspondence: Roya Rouzbahani, Faculty of Arts, Alzahra University, Iran. E-mail: \\ rozbahani9494@gmail.com
}

Received: February 10, 2016 Accepted: March 7, 2016 Online Published: May 20, 2016

doi:10.5539/ass.v12n6p123

URL: http://dx.doi.org/10.5539/ass.v12n6p123

\begin{abstract}
Nature has always been an important element of myths and religions and had a different standing within ideologies. Because various factors have been involved in creation of myths, this research aims to clarify the role of nature in creation of Iranian myths. Generally, the structure of Iranian myth is a kind of belief in duality of nature, in human and in the conflict forces existing in the world which best are expressed in the continued conflict between good and evil forces. Iran is a country with varied natural geography and can be called the land of great conflicts, so this paper aims to investigate the role of nature in the creation of Iranian myths and determine the effective natural and mythological forces. Data gathered by the documentary method and the research was performed by a descriptive, adaptive and analysis method. According to the results, this research concludes that natural elements play a significant role in the Iranian myth.
\end{abstract}

Keywords: myth, nature, legend, Iran

\section{Introduction}

Knowledge about myths can be very useful from the aspects of access to the basis and origin of limiting factors of mind and social behaviors or the stimulating and encouraging factors in the present time. Knowing about the roots of thoughts, imaginations or beliefs can help us getting a kind of freedom.

The rich wealth of Iranian legend and myth has been passes on for thousand years of civilization. The ancient artistic works are proper source of Iranian myths. But the most important Iranian myth source is Avesta, the sacred book of Zoroastrian. Unfortunately only one fourth of the original book that is used in religious rite is accessible for us. From the Persian sources, we can refer to Ferdowsi's Shahnama which is the main source of Iranian mythological and epic narrations. Figures remained from Achaemenid, Arsacid, and Sassanid empires on the walls, coins, and dishes which show a picture of past gods and heroes with some texts about them, a key for texts with the mythical topics.

The first challenge for every researcher in the area of mythology is to answer the question of how myths have been created and what factors are involved in their creation. Scholars have different views in this regard and there has been a lot of discussion on this issue. The present study is also based on this problem and with a fundamental view toward creation of myths to find the role of nature in creation of the Iranian myths. From ancient times Iranian have respected the creator and guiding forces of nature and regarded them as holy.

Generally, the structure of Iranian myth is a kind of belief in duality in nature, in human and in the conflict force existing in the world which is best expressed in the continued conflict between good and evil forces from the beginning of creation.

\section{Methodology}

Data gathered by the documentary method and the research was performed by a descriptive, adaptive and analysis method.

\section{Discussion and Results}

\subsection{Concepts and Definitions of Myth}

"Myths are symbols of human experience and visualization of spiritual values of a culture. Every society has its specific myths and tries to keep them because beliefs and worldview of every culture is its definite factor of immortalization" (Ruzenberg, 2007, p. 17). 
In addition to the world justifying role of myth, it justifies the role of human in the world. "Myths nearly affect every person who is in a kind of relation with the world's infinite joy and charming magic. Old human was in search for answer to his questions, he was in challenge with unknown things and in the time of lack of science and developed role and without an authorized source for answering questions, he tried to find great answers within stories and in this way a collection of assumptions was formed as myth" (Shiri, 2008, p. 106).

In the common language of the $19^{\text {th }}$ century, everything in conflict with fact was called myth: Creation of Adam, or Invisible man, World history by description of Zulus, Theogony by Hesiod all were myths and like so many other intellectual and positivism clichés, their roots and structure originated from Christianity; because according to the early Christianity, everything not justifiable with Torah or Evangelija, cannot be true and was regarded as a "myth". Ethnologist studies persuaded us to look at the basis of semantic heritage from the point of view of Christian polemicist against an unchristian world. We should begin getting knowledge about value of myth as it has developed among the primitive and ancient societies who had myth in their basis of social life. In this regard it comes to mind that: as if in these societies myth has stated as pure truth because it retells a sacred history; it means an ultra-human inspiration in the Great time in illo tempore" (Eliadeh, 1995, p. 23).

There is a clear history of the word of "myth" in the Persian language. It means that there is no such record. In all of old literature we just can see the word in a pair of verse lines in one of exemplum of Khaqani:

"Do not put the key of myth of Aristotle on the door of the best nation"

This dates back to one thousand years ago; then until midway through the Qajar dynasty when compilation of bilingual dictionaries is started here and there, there is no trace of the word of myth in the Persian language" (Daryabandari, 2000, p. 187).

The Persian Encyclopedia states myth as superstitious or semi superstitious stories about the supernatural ability of gods or heroic stories of humans which have passed on successive generations as narrations. It mentions that these kinds of stories are different from the fairy tales. Historians have always claimed that they write about facts and believed that myth authors retell unlikely, incorrect and (as Plato said) immoral legends. On the other hand, these historians never were doubtful about correctness of some of myths (especially stories related to Trojan War). But today it has mostly been accepted that myth and legend is based on historical facts. Of course except in a very weak concept, there are a lot of mythological issues with no historical basis (Warner, 2007:13). It is worth mentioning that the historical accuracy of myths does not matter but their value before their followers is the point.

John Hinnells proposed about the nature of myth that

"Myths are not only statements of human thoughts about the fundamental concept of life; but they are instructions which guide the human life and can be a logical justification for society. They are design that the society gained its ultimate credit through mystical imaginations, either these imaginations are about gifted authority of kings of England in the Stewart era or three - sectional model of society from the view point of India and Iran. According to the recent theory, society has been created with a three-level structure: some people are spiritual, some are warrior and some are created as farmer. Therefore all of people relate their own rank in life to gods' will. Myths also can be regarded as advices in a prominent moral system and provide people with models to develop their life" (Hinnells, 1998, p. 23).

Although there are various definitions of myth, we can define it as "myth is a symbolic narration of gods, angels, supernatural beings and generally worldview of a nation; myth is a sacred and truth story which has taken place in eternity time and in an imaginative and symbolic way speak about how something has created, has existence and will be vanished, and finally myth is a prober of universe analogically" (Emaeilpour, 1998, p. 14).

What makes myth distinctive from story is its use in religion. "Myth has a religious and philosophical basis; it is philosophical because it is an analogical argument about world. The mythological narrations can be about universe, nature, human or devil forces. It sometimes justifies the death source and sometimes determines the fortune of gods and heroes" (Esmaeilpour, 1998, p. 14).

Roger Bastide, in his book of "Mythes et utopies" believed that myth can be something other than narration of allegory or story and regards picture as other possible format of myth; "we are right to regard the pictures and drawings on the walls of Lacsaux cave, some sculptures in frontispiece of church and many other pictures as myth, because all of these imaginations include a mysterious picture of social facts which are accounted as essence of myth. So, myth can be a picture, and can be expressed in any language even if that language be voiceless" (Bastide, 1991, p. 45).

"Myths from the first have been created as entertaining stories but with serious aims and purposes. Their 
attraction has bestowed them a hundred and even thousand years lifelong. The main aim of a myth is to explain the essence of universe (creation and fertility myths) and teach the society members to adopt what kind of behavior, and method to improve their life and activity (myths and heroic epics) (Rosenberg, 2007, p. 18). We can also say that "myths and epic stories of every society teach the values, method of life specific to the same culture to members of society. These myths have specific values for us. These are not only exciting adventures, but also we find ourselves greater and splendid than while we became aware of our defects and our potentials" (Ibid, page 20). Myth like science aims to explain about the world realities. "Myth recounts us influencing factors of the world and learns us about their physical and spiritual nature" (Vali, 1990, p. 116).

\subsection{Geographical and Natural Location of Iran}

Iran is bordered by Turkmenistan, Azerbaijan and Caspian Sea to the north, Afghanistan and Pakistan to the east, Gulf of Oman and Persian Gulf to the south, and Iraq and Turkey to the west. "Iran territorial border extends $5050 \mathrm{~km}^{2}$ long and its marine border extend $3050 \mathrm{~km}^{2}$ " (Neysari, 1971, p. 6). "Iran is located in the east-southern part of Asia. The east-southern Asia is an intermediate region between the three continents of Asia-EuropeAfrica. Iran is strongly under effects of events in these three continents" (Badiei, 1988). "Iran is a highland country with more than two third of land above one thousand altitude which just 21 percent of its surface is below 500 meters. Its average altitude is above one thousand which is comparable from this aspect with few countries such as Tibet, Turkey and Bolivia. Iran mountain range stretches into most of local basins" (Haririan, 2010, p. 6).

Most of the area of Iran is comprised by mountain and highlands. This country has different topographies and its mountain has special specifications which is the reason of various natural and economic conditions of different parts of the country. Different structure, land surface, great altitude differences and other factors have caused varied conditions (Figure $1 \& 2$ ), which can be divided into the three distinct parts of mountainous, coastline and internal plateau regions" (Badei, 1988, p. 42).

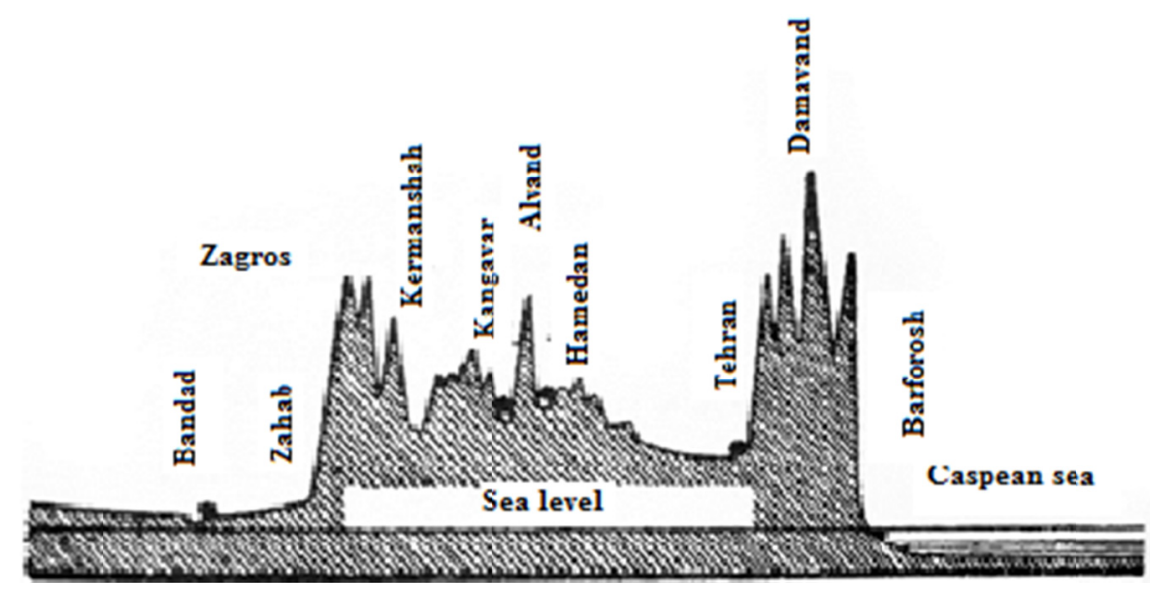

Figure 1. Iran plateau section between Persian Gulf and Caspian Sea (Ghirshman, 2011, p. 28) 


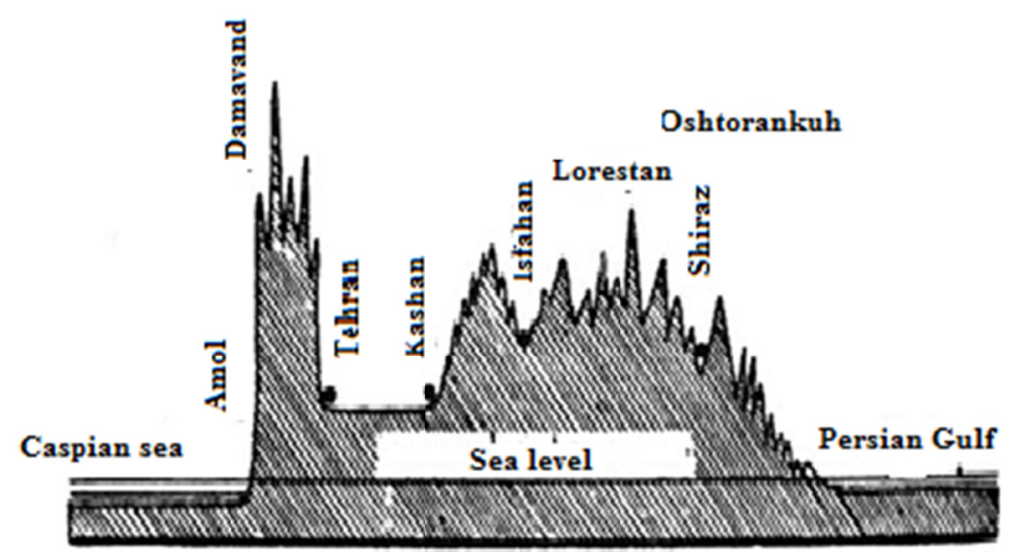

Figure 2. Iran plateau section between Baghdad and Caspian Sea (Ghirshman, 2011, p. 29)

Generally we can divide Iran roughness into four distinct districts from the aspect of nature and prominence orientations:

1. Northern mountain range of Iran including Azerbaijan, Alborz, Khorasan mountains

2. Eastern mountain range of Zagros or Patagh including frontier mountains of west-north, Kurdistan, Lorestan, Bakhtiari, Fars and coast mountain of Persian Gulf and Gulf of Oman

3. Central mountain range stretching from Qaflankuh in Azerbaijan to Baluchestan

4. Singular eastern mountain (Ghirshman, 2011, p. 28).

Iran is located in the arid mild northern part climate region, in the average latitude of earth and subtropical and tropical area. This geographical location and remoteness from great seas and especially aerial movements have caused the dry and short fall climate of Iran. "One of main features of Iran climate is its excessive dryness in summer; with this feature Iran is among regions with Mediterranean climate. Iran and areas of northern Africa beside Mediterranean Sea, and northern part of Africa Sahara all are located on the same latitude. Even during cold season rain does not fall continuously and just in few days the rain fall is increased" (Behnam, 1958, p. 11).

\subsection{The Role of Forces of Nature and Their Effects on Myths}

After the geographical studies and the nature of the large country of Iran, here we want to investigate about role of elements and natural forces influencing Iranian myth.

\subsubsection{Water}

Water is one the four main elements and important concepts of nature which has been always in attention of humans and stimulated their praise and worship. Ancient Iranians regarded water sacred. This element is one of the main elements of mythology, cosmology and eschatology and even in some cases has found spiritual attribute and has been related to great gods (Ghirshman, 2007, p. 32). According to the order of creations of Hoormazd (which have been mentioned in the old texts), and including of water among the first creations of God, the influential role of water for life of beings become cleared and we can say definitely that without water nature will be destroyed; therefore water is very respectful among Iranian. "In seven hymns of Avesta different waters have been respected, from fountain until end, from ice-snow fountains to ponds in mountains, springs, rivers and seas and also seasonal pluvial clouds which rise from sea and make water flow from mountains" (Ghoreishi, 2010: 206). In the Pahlavi texts water has a specific stand. Followed by sky, water is the second material creature of Ahura Mazda and from Amesha Spenta (the great six "divine sparks" of Ahura Mazda) Haurvatāt (Khordad month) accepted water. Water is opposed to devil (Faranbagh dadgi, 1990, p. 65). As it was mentioned, ancient Iranians regarded the useful and effective elements as sacred and supposed it to be a guardian god. Water is one of useful elements which has been worshiped and through Avesta it has mentioned with holiness. The God of guardian of water, has been mentioned with the names of Aban, Aredvi Sura Anahita (= Nahid) who has the follower of Apam Napat (son of waters) or Burz Izad or Aban Naf who has the duty of sharing waters. Khordad Amesha Spenta is the lord of water which, according to Bundahishn book (meaning "Primal Creation"), the origin of universe is from water.

Aban is one of gods of water. The fifth hymn (Yasht) which is called Aban yasht praises the god of water. "This 
yasht is one the most attractive sections from the ancient. In Aban yasht ecept praise of angles we can see the names of many ancient famous Iranians. In Yonger Avestan there is a yasht in praise of Aban which was hymned beside rivulets, fountains and waterfall. Aban god is one of partners of Esfandarmaz Amesha Spenta. In the Iranian ancient calendar, tenth day of each month and eighth month of each year were called "Aban god" (Afifi, 1995, p. 402).

In the Old Iranian narrations, water is goddess of life giving. Anahita, the goddess of rain, makes rain fall everywhere she walks and also makes fields green and pleasant. One of the most beautiful parts of Avesta is called Aban yasht or praise of water (Pourdavod, 1977, p. 259). According to Avesta instructions, Anahita is a prominent figure in the ancient Iranian creeds and was praised by people (Dustkhah, 1991, p. 297).

It is worth mentioning that Sura Anāhita goddess (strong army) with the name of Anahita, meaning pure and strong water, is the origin of all the earth water. "She is the source of all fertilities; she purifies sperm of all masculine beings, purifies uterus of all feminine beings and also clean milk in breast of mothers. While in her heaven stand, she is the origin of cosmic sea (Dadvar \& Mansuri, 2006, p. 128).

\subsubsection{Rain}

Rain, from the aspect of Iranian myth, is a divine phenomenon. According to what has been mentioned, a great part of the Iran plateau is covered by dry desert (Dasht-e Kavir in the northern part of Iran and Dasht-e Loot in the south of Iran. This phenomenon has exposed Iran to the draught threat. In an inscription in Persepolis (Dpd clause 3), Daruish pray God protect iran against draught and lying. In such conditions, it is logical that some myths related to rain are created.

Tashtar is the name of god and star of rain. In Avestan language, it is called Tishtrya, Tishtar in Pahlavi, Tir or Tashtar in Persian (Afifi, 1995, p. 475). According to the ancient Iranian narrations, in the beginning of creation, when Ahriman attacked sky and land, it was arid with no sea. Then Tishtar, the splendor angel of rain bearing, made cloud to appear to the west during sunset and move it in the sky and made rain fall for thirty days and nights. Every drop of that rain was as big as a water basin. The height of water reached a man's tallness. Then winds drove all that waters to the shore of the world and oceans, which are called Vourukasha, were created (Bahar, 1998, p. 553).

\subsubsection{Mountain}

In every part of Iranian plateau, the high mountains have been praised since the time people chose this land to settle and they also have been safe shelter to protect against natural destructive forces or invasion of other people. Mountains haves been the first shelter for human and a source rich I food and water for human. It has expressed in different forms within the culture of Iranian plateau and has a high stand in the Iranian myths.

"Mountain has very important perspective. It has a complete and fascinating volume and absorbs human eye from the material world into sublime" (Nosrati, 2001, p. 106). One of main points of mythological insight toward the mountains is their mysterious aspect in relation with God. Silence and highness of this magnificent vision of nature is a way of relation of the humble world with divine world and this aspect of myth is also found in other nations' literature.

About creation of the world in the Iranian myth it has been mentioned that Ahura Mazda created the earth in the third part of creation. "Ahriman splited it and went in, then by an earthquake the mountains grew in the earth surface. In Avesta this name has been mentioned as Kaofa, Gaeri which in Pahlavi is Kof or Gar. Mountain in Avesta has been mentioned with the adjectives of cleanness, peace and tranquility and has been regarded sacred between Iranians" (Afifi, 1995, p. 592).

"In Avesta a mountain has been mentioned with the name of Asya which in Pahlavi texts has been used in different ways with meanings of stand of rest, wealth and peace (mostly from the aspect of spirit and mental). This name has Iranian root of say/su meaning rest" (Gharshi, 2010, p. 166).

In Pahlavi texts, we also see name of mountain and creation of mountains has been mentioned as the result of the third level of fight of the world creators with demon assault. In Bundahishn book, we read that "in the third level of battle the earth was created. With assault of Ahriman earth shook, and from that shaking mountain grew on earth. First there was the divine fortune Alborz range in border of earth, and then other mountains in the middle of earth; because when Alborz grew, all other mountains stand on it, because all of them have root from Alborz like trees which grow their branches upward and root inside. Their roots are bonded together in such a way that after that earth cannot shake. This is why the largest mountain is called holder of lands. Waters have origin in mountain. Roots of mountains is in up and down path to let water in and out; such as root of trees in earth which are like veins in body which feed all parts of body" (Feranbagh dadgi, 1990, p. 65). 
Within the old texts, mountains, especially the mythological mountain of Alborz, has a special stand. According to Avesta, Alborz is the first land and governs all territories (Bahar (b), 1998, p.97). There has been stated so many texts about importance of Alborz mountain such as its closeness with the cosmic sea. Vourukasha Sea or endless cosmic sea is a mythological sea and covers one-third of the earth (Amuzegar, 1997, p. 61).

Mountain has proximity with kings. "According to the Pahlavi texts, Kay Kāvus who dominated seven countries, made seven houses over Alborz Mountain from where governs all and even demons of Mazandran" (Amuzegar, 1997, p. 61).

The holiness of mountain and its position as a place of saints has reflected in Shhnameh and mysterious and beautiful stories of Shahnameh are tied with a mountain and especially Alborz. Within the pre-Islamic belief, except of Heom and its god with mountain, Mitra also had relation with God and so why Mithraists prayed in mountain. Herodotus about Persian worship during Achaemenid Empire writes that "worship was not done in large meeting house but in an open space over mountains. Persians climb to the top of mountains and sacrifice for Ahura Mazda (Gharshi, 2010, p. 167).

\subsubsection{Earth}

Review of ancient beliefs and creeds shows us that land is the mother of all beings and that they grow from land and everything which has been created from it is alive and then returns back to the earth and relives. Earthy humanity may be another interpretation of this birth from earth since fate of land is a continuous birth and rebirth of all things (Eliadeh, 1997, p. 249).

Land is one of the useful elements which have been regarded sacred by ancient Iranians. This belief can be a logical basis on the old pastoral and agricultural traditions (Armstrong, 2011, p. 30).

Iranian myths refer to the creation of earth in the third level followed by the creation of water. In Avestan language, this word is Zam and in Pahlavi language it is Zamik. "In hymn of Farvardin, Ahura Mazda addresses Zoroater that these are because of bless and glory of fravashis (the fine internal forces) that I keep the wide land carrying beautiful things of the material world" (Afifi, 1995, p. 546).

"Earth, mother, mother of existence, farm; in Iran, Amesha Spentas is the goddess of earth. she is beneficent and profitable goddess who is also breeder of creators, daughter of Ahura Mazda, helper of cattle, cherisher of pastures, healer and the daughter of sky god" (ESmaeil pour, 1998, p. 20). Within the Iranian myth, earth also has gods. "Zamyad is god of earth and his name has been mentioned beside Arshtat god. These two judge about soul of deceases. Along with Ashtat and Rashan gods, Zamyad is among followers of Amordad Amesha Spentas" (Vandaei, 2011, p. 201). In Pahlavi text, we can read about earth and its creation. In Zādspram book, the third battle of Ahriman and followers is with Ormazd (earth) and it is said "in the third level earth prepared itself for battle with Ahriman. In such a way that because of cracking and shaking of earth, Alborz appeared beside earth and other mountains appeared in the center of earth which their counts amounted to two thousand two hundred and forty four mountains" (Ibid, p. 546).

\subsubsection{Plants and Trees}

"Iranian rural herder tribe from the time that trod foot on this land and started life along oases, valued water and tree because they were not plentiful and a fruitful tree may be the result of labor of several past generations who made aqueducts or wells for agriculture and it is obvious that its result has holiness" (Farvashi, 1995, p. 89). Before the ancient tribes, the tree has a mythological nature and is full of symbolic and rich themes. In Bundahishn, there is a part about plant creation in the section of material creation which says that Hormuzd "created plant in fourth level, It first was grown at the middle of earth which was upward, without branch, without skin, without horn, fresh and sweet and had all forces of plants inside" (Franbagh dadgi, 1990, p. 40). One of connection forms of human life with plants is belief in worthiness of trees and flowers. Plants are exciting spiritual and holy symbols of human mythological conscience in relation with God. "Tree with roots in the ground and branches extending to the sky is a symbol of relation between earth and sky and trend toward top and has relation with the three worlds of underneath (hell), middle (earth) and sublime (paradise)" (Fazeli et al., 2013, p. 21).

In addition to the aspect of the tie between earth and sky, tree is also regarded sacred from the aspect of its life bearing and fertility. The mythological importance of the tree can be found from the story of creation of first mother and father, Mashya and Mashyana. In Bundahishn, we read that "when Keyumars died, left sperm, the sperm became purified as light as sun. For forty years those were in arid land. After that, Rhubarb plant grow, with fifteen leafs, from which Mashya and Mashyana grow (the first man and woman), as if they are standing with hands on ears, connected to each other, with same height and structure" (Franbagh dadgi, 1990). 
The importance and sacredness of both plant and tree in Iranian myths and beliefs are reflected as "tree of life" (Figure 1). "Tree of life" which usually is seen in pictures and scripts positioned among two monks, priest or two mythological creatures as its guardian, is regarded as secret of sacred force. To pick its fruits which results in elixir of long life, one should fight with its guardian monster. Everyone who wins the battle can get the supernatural level and immortality" (Dubuker, 2008, p. 13).

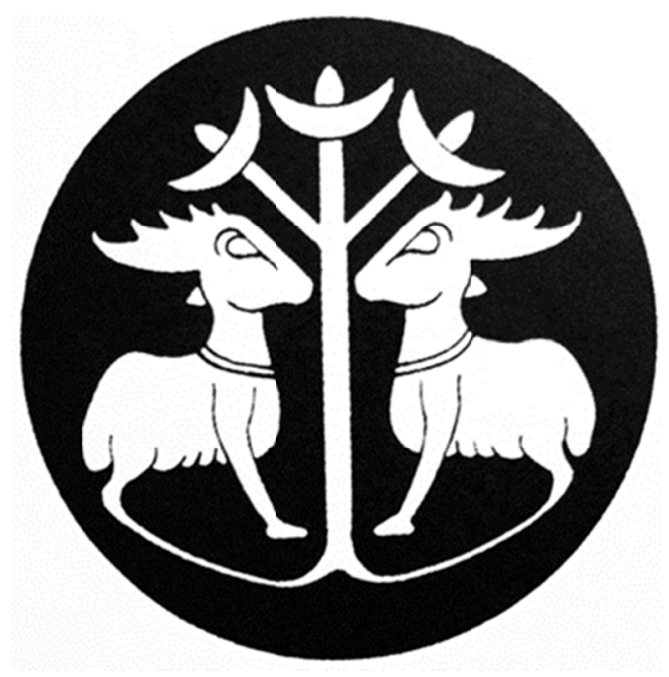

Figure 3. Mark of imprint of Sassanid era, image of two horned animals on both sides of date-palm (life), (Dadvar \& Mansuri, 2006, p. 103)

Cedar also has been in attention from the old days and has been the special sign of Iranians. Among the desired signs of Iranians, we cannot find a symbol as acceptable as Cedar. In the Iran plateau, with its dry and warm condition, Cedar is a symbol of persistent life and prosperity. This ever green and raised tree has had a special stand among Aryan tribes and in sculptures of Perspolis has been used with detail intricacies and horizontal branches. During Achaemenid and Sassanid eras, this tree has been used as the life tree.

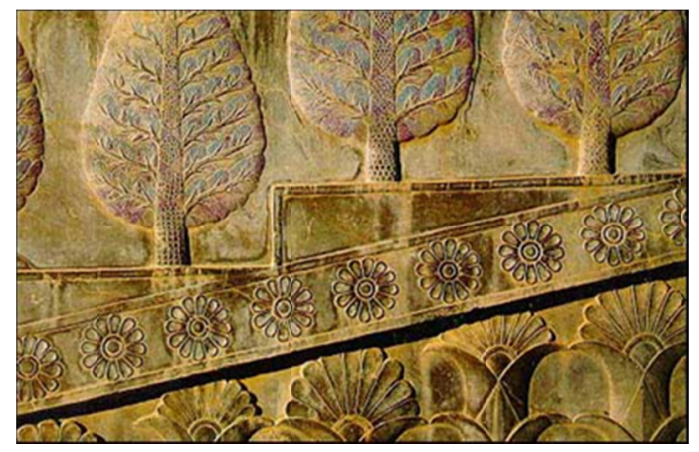

Figure 4. Picture of Cedar and Nenuphar flower on the body of eastern stair of Apadana palace, Perspolis (Dadvar \& Mansuri, 2006, p. 102)

Nenuphar flower is one of plants which has had been paid attention to in ancient Iran. "In the ancient old myths, the Nenuphar flower is attributed to Anahita" (Motakef, 2006, p. 10). Nenuphar flower is a symbol of life and creation from the aspect of Iranains which its first emergence is with Mithraism. "In old Iranian tradition, Nenuphar flower (Lotus) was regarded as a place for keeping sperm or glory of Zoroaster which was kept in water, and so Nenuphar has a close kin with Mithraism" (Dadvar \& Mansuri, 2006, p. 104). 


\subsubsection{Animals}

Cow is one of the repeated animals in Iranian myths. In ancient Iran, cow was regarded the most useful animal. Bull or bullock was a working animal providing a diet basis and was very worthy for agriculture. It was also used for wheel turning and transport. So, it is not surprising that cow is very respectable in Zoroastrianism and its guardian angel is invoked.

This useful animal has a grand stand within Iranian myths. "Cow rank in the earth is equal to stand of Taurus in heaven, because it has effective role in cultivation of land and also is a sign of Mitra. In a hymn of ancient Iran, bull has been mentioned as blessing and reason of all goodness". Cow in Iranian myth is a symbol of the moon and has relation with land fertility. "In ancient Iran, the horn of cow is a sign of mind, sun or moon. Tishtar, the god of rain, also sometimes is expressed as a cow" (Dadvar \& Mobini, 2008, p. 118).

Horse is a clever, faithful and effective animal in human life. Loyalty, power and speed of this animal has bestowed it a grand standing in myths. The horse name in Sanskrit is written as ASva, in Avesta as Aspa, in ancient Persian as Asa, and in Pahlavi as Asp. In the Avestan literature, role of horse within mind and life of people was in such a way that each of gods has dealt with this animal in kind. In Avesta the angel of beasts is called Druvaspa. Iranian attitude toward horse was a mythological view which in myths helped them. The mythological face of horse most of all is expressed in narration of Tishtar battle with Apaosha (demon of draught). In the hymn of Teshtar we can read description of this battle. According to this hymn, the battle took place in thirty days and during this time, Tishtar flew in three forms that of a fifteen years old young, a golden horn cow, and white horse with golden ears and bridle. Horses remain beside heroes in all of difficulties and help them in their critical moments, and all these values probably are the result of the important role of horse in the economic and social life of people. The role of this valued and mythological animal can be found on many of old remained works.

Lion in Iranian myth and epics is a creature with two holy and satanic functions. The holy function is appeared from figure of the lion on Old Iranian flags and inscriptions and lion sculpture was gifted to kings and heroes; even in some of heroic poems we can see traces of lion worship; the satanic aspect of lion is because it has regarded in a level with dragon. Winged lion in stone pillars of Babol and Perspolis is an imagination of storm or chaos monster that sometimes has been shown with eagle head (Dadvar \& Mansuri, 2006, p. 75).

\subsubsection{Fire}

Fire has been one of important aspect of nature for human and discovering of fire has been a starting point of human civilization. Symbolism of this critical element has been expressed by different aspects in myths and religious narrations and in addition to the mythological aspects it has found metaphorical aspects during latest civilization era and also has found intellectual concepts along with light which has always been its companion.

In ancient Iran, creation of fire "from two pieces of stone as attributed to time of Hushang Pishdadi which has been remained in Sada festival which is also common today “ (Afifi, 1995, p. 405). The guardian angel of fire in Pahlavi language is Aturizet and Azar god in Persian and because of important stand, this angel has been called son of Ahura Mazda. Ancient people used odorous wood in fire temples and the fire place at homes to please the angel of fire. Iranians respected fire. "The ninth month of year and ninth day of month is called Azar (means fire) in Persian calendar. The guardian of this month and day is Azar god. Here was a festival of "Azargan" or "Azar festival" in the day of Azar of Azar month in which day and month became concurrent" (Shiri, 2008). Today also this is common among Zoroastrians.

Generally, the most important feature of Iranian myths is their world view and belief in duality and existence of evil and good, or satanic and divine forces. According to the geography of Iran, we can say that Iran is the country of clash of good and evil. This is a land of mountain and plains, desert and jungle and seas. This land has unusual geographical variation and ethnical climate. According to the roughness of Iranian plateau, this land includes humble and high areas like plain and mountain. Therefore, structural differences of land surface are among the natural conflicts. Iran weather also has significant variation. We can say that Iran has a continental climate which sometimes is very cold and sometimes very hot. There is intense temperature fluctuation during different seasons. Rain falls beside Caspian beach plenty and there is lack rain in some parts. We can conclude that Iran nature has harsh differences.

\section{Conclusion}

As the studies showed, ancient Iranians regarded the useful natural phenomena and world's creatures as sacred and a god as guardian for them. According to what is said, there are a lot of natural resources in nature from which the myths have originated. In fact, nature and its useful elements had an effective role in myths' creation 
in such a way that most of myths have centered on these elements. Even in simplest forms, myths are a collection of narrations, usually sacred, about gods, supernatural beings and amazing events in beginning time, which have taken place with different qualities from that of our time and led to creation of the world. It is surprising that myths don't try to establish these narrations and their followers are not doubtful about their truth, even though these narrations seem unbelievable. Generally speaking, according to the result, among different factors leading to mythic creation, nature and the conflicts within it have had an influential and significant effect on formation of such beliefs.

\section{References}

Afifi, R. (1995). Iranian myth and culture in Pahlavi text. Tehran: Tus Press.

Amuzegar, G. (1997). Iranian mythological history. Tehran, Organisation of study and development of Humanitarian books of universities, SAMT Press.

Armstrang, K. (2011). Short history of myth. Translated by Abbas Mokhber, Tehran, Markaz Press.

Badei, R. (1988). Detailed Iran geography (Volume 1). Natural geography, Tehran, Eghbal Press.

Bahar, M. (1998). From myth to history (Ed: Abulghasem Esmaeilpour). Tehran, Cheshmeh Press.

Bastid, R. (1991). Myth knowledge. Translated by Jalal Satari, Tehran, Tus Press.

Bastide, R. (1960). Mythes et utopies. Cahiers internationaux de sociologie, 28, 3-12. Translated by Jalal Satari.

Behnam, E. (1958). Iranian civilization. Iranian Tehran, Tehran, Translation and publish institution.

Dadvar, A., \& Mansuri, E. (2006). An introduction to myths and Iranian-Indian symbols in ancient times. Tehran, Kahor and Alzahra University Press.

Daryabandari, N. (2000). Legend of myth. Tehran, Karnameh Press.

Dubooker, M. (2008). Secrets of alive man. translated by Jalal Satari, Tehran, Markaz Press.

Dustkhah, J. (1991). Avesta (Volume 1). Tehran, Morvarid Press.

Eliadeh, M. (1995). Myth, dream, secret. Translated by Roya Monajem. Tehran, Fekre ruz Press.

Esmaeilpour, A. (1998). Myth, symbolic statement. Teharn, Sorush Press.

Gharshi, A. (2010). Water and mountain in Iranian and Indian myths. Tehran, Hermes Press.

Girshman, R. (2011). Iran from beginning until Islam. translated by Mohammad Moein, Tehran, Negah Press.

Hinnles, J. (1998). Knowledge about Iranian myth. translated by Gale Amuzegar and Ahmad Tafazoli, Tehran, Avishan press and Cheshme Press.

Neysari, S. (1971). Generalities of Iranian geography. Tehran, Bina Press.

Nosrati, M. (2001). Importance and place of holy and heaven mountain. Mah Honar Magazine, 102-107.

Purdavoud, E. (1977). Yasts. Tehran, Tahuri Press.

Ruzenberg, D. (2007). World myth: Stories and epics (Volume 1). Translated by Abdolhosein Sharifian, Tehran, Asatir Presss.

Shiri, A. (2008). God of fire in Iranian myth and ancient Greece. Mahe Honar Magazine, 106-115.

Vali, A. (1990). Women in Iranian myth, Life of women in Iran history. Tehran.

Vandaei, M. (2011). Iranian myth. Hamedan, Islamic Azad University.

Warner, R. (2007). Glossary of world myths. translated by Abulghasem Esmaeilpour, Tehran, Ostureh.

\section{Copyrights}

Copyright for this article is retained by the authors, with first publication rights granted to the journal.

This is an open-access article distributed under the terms and conditions of the Creative Commons Attribution license (http://creativecommons.org/licenses/by/3.0/). 